\title{
THE UNCONSCIOUS KNOWLEDGE OF THE SUBJECT AND THE DESIRE OF THE ANALYST IN THE DRUG CLINIC
}

\section{ORIGINAL ARTICLE}

ROCHA, Lorena Fabiani da ${ }^{1}$

ROCHA, Lorena Fabiani da. The unconscious knowledge of the subject and the desire of the analyst in the drug clinic. Revista Científica Multidisciplinar Núcleo do Conhecimento. Year 05, Ed. 04, Vol. 01, pp. 152-161. April 2020. ISSN: 2448-0959, Access link in: https://www.nucleodoconhecimento.com.br/psychology/knowunconscious

\section{SUMMARY}

The clinical care to drug patients requires that unconscious dimensions of the subject who drugs and the accompanying analyst be observed, considering that these dimensions precede and imply the patient's condition of dependence. Thus, this work aims to clarify psychoanalytic perspectives that guide the approach of the toxicomanphenomenon in the setting of care. Concepts such as "unconscious" and "analyst desire" were taken in order to elucidate how the analytical situation constitutes an individualizing treatment and is opposed to the classical psychiatry method. Therefore, it is emphasized the existence of a particular knowledge in each patient about his drug addiction, which was not predicted by medical nosology. Therefore, the psychiatric technique is considered insufficient and an approach is explored that seeks to better interpret drug addiction, having as a tool to base the analyst's desire. In addition to the central concepts brought by the title, the work also goes through the notions of "language", "malaise in culture", "I", "monomania", "castration" and "drive maturation". The research started from the bibliographical investigation method, referring to the theme "Drug addiction" in the scope of Psychoanalysis and classical

\footnotetext{
${ }^{1}$ Graduated in Psychology.
} 
psychiatry. The literature of consecrated authors who cross-trust such knowledge, such as Freud, Lacan and Bercherie, was used.

Keywords: Drug addiction, analysis, clinical care, classical psychiatry.

\section{INTRODUCTION}

Drug addiction is a phenomenon that needs to be studied beyond drug practice. In view of this, psychoanalysis presupposes an ethics and operates from an unconscious knowledge that produces jouissance. The discovery of this knowledge stems from the experience of an analysis process. Thus, by admitting the desire that holds the last and particular truth of the subject, the method postulated by Sigmund Freud is opposed to the way classical psychiatry from Pinel dealt with this phenomenon until the beginning of the century. XX.

The present research is guided by psychoanalytic theory, that is, it considers the discovery of unconscious knowledge that affects the speaking being in an individual way, which makes the life history of each subject a specific way of inhabiting language, in line with its libidinal economy. This language, in turn, makes us inhabit the malaise of culture and confronts us with objects offered by the capitalist's discourse to buffer the irreparable lack that marks human existence. In this sense, the analyst's desire challenges the discourse of science that has been included the subject of speech, language, subjectivity. Based on this premise, the research aims to answer the following question: what is veiled by drug addiction, and how does the analyst's desire in the drug clinic work?

Therefore, the objective of this work is to point out how the analyst's desire constitutes a clinical tool and how it approaches intoxication, from the unconscious and the drive. The importance of this research is to take the phenomenon in its double social and subjective value, expanding the reductionist view and the phenomenal approach to the theme. To fulfill the objective, the method used in our study was the bibliographic research of renowned authors such as Freud, Lacan and Bercherie, who address drug addiction in the context of Psychoanalysis and Classical Psychiatry. The research was 
the result of the Scientific Initiation Project of the Veiga de Almeida University (PIC UVA 2019) and guided by professor and psychoanalyst Clara Lúcia Inem.

\section{RESULTS}

From the present study, the finding was derived that all knowledge comes from the manipulation of a language that is pre-he (LACAN, 1954). It is about human language, essentially symbolic and particular, so that here, it has exclusive possession of meaning in the toxicomaniac phenomenon. Thus, this bibliographical investigation reaffirms a method that opposes the nosological model of psychiatry, by subjectivation the phenomenon in question.

It was noticed that language has primacy in the functioning of the subject and denounces intoxication as a secondary process. From there it is understood that the practice of the drug veils the true symptom with the personal interpretations of the patient since the beginning of its constitution. It is inferred, then, that the imperative of treatment is the attribution of a symbolism to the manifestations of the subject (LACAN, 1955), and we achieve that, the symbolism present in the toxicomanrepetition says of a disillusionment of the patient in relation to the other (FREUD, 1927). Having said that, the condition of subjection of the patient is first clarified, and then considers drug practice as a puzzle.

Finally, it was observed the substantial role of the analyst's desire in the management of this phenomenon. This is because this desire desists out, because it offers itself as a place (QUINET, 2000) to install the patient's matured desire. It is in this direction that the analyst's desire points out: instead of the monotonous repetition and the shortcircuit drive promoted by intoxication, lead the subject to a mature desire, which recognizes and invests in himself. These are the questions that are presented to us: an intoxication of language where the signifier fails and does not allow the body to be metaphorized by unconscious knowledge. 


\section{DISCUSSION}

\section{OF TOXICOMANIA AS THE PRODUCT OF A SUBJECTIVE MALAISE IN PLACE OF EPISTEMOLOGICAL SIGN}

From a discussion about the possible origin of religiosity in "The Malaise in Civilization", Freud (1930) specifies some unconscious mechanisms that the human being engenders to deal with the anguish of inhabiting a world with which he discovers he has no relationship of unity, and which constitutes a hindrance in his search for happiness. Among these mechanisms participates intoxication, as an attempt to recover a satisfaction lived at the beginning of life, and that not being able to be recovered, leads to repetition.

Thus, we recognize that the current self of the subject is what unfolded from his infant version (FREUD, 1930) after a disappointment. However, the self covers an unconscious layer, which instead of appearing the subject as one, says of its impulses more passively put to the test of dissection, as they guard desire. The toxicomaniac phenomenon is then taken in relation to these impulses. Therefore, it is ineffective to observe and classify drug practice objectively as classical psychiatry proposes. This method would lead the analyst to indulge in the analyzing when it brings the drug as an identity mark. Thus, as the analyst does not respond from the place expected by the patient - that is, the place of teaching - making his act as unknown as what hides under the subject's self, there is an analytical doctrine that houses an indispensable gap, which is opposed to the knowledge of psychiatry, which already exists exhausted before the experience with the patient.

To found an alternative path, it is understood that the patient must first trust in the belief that the professional knows about what he brings as disorder. However, it is only when the analyst makes use of such an assumption to cause the subject to recognize the cause in himself, that one finds the undoubted success of a procedure.

It is understood here that intoxication is not the symptom, but it veils symbolic mechanisms that already have word value and carry their own meaning (LACAN, 
1953). That said, taking other paths to decipher the puzzle would only embarrass things. Naming what already carries in itself a signifier, puts us a new path outside the subject, and therefore with no way out.

Still - in the remora us Bercherie (1989), Pinel did not dispense with formulating a vast nosography that made him qualify drug addiction as madness of impulse, mania without delirium, and finally, monomania. However, psychoanalysis does not consent to the attitude of ending the understanding of drug addictions as impulses of moral cause, taking them solely by excessive forbidden and lasting passions. Although the toxicomanact is considered an attempt to subvert the culture of moderation of impulses, it is not proceeded to dominate them, on the contrary, it is used for them to ascend to more mature mechanisms. Thus, the analysis investigates the affections deposited in the drug, and the constancy itself in drug addiction is taken as an effect of the cause, never as the cause itself.

Psychiatry, in turn, perceived the moral causes as the most numerous and producing a type of 'visceral disturbance' (BERCHERIE, 1989), propagating the madness of impulse by irradiation in the body. It is interesting to note that for psychoanalysis, the cause of the toxicomanphenomenon also makes a path by irradiation, but this is the significant chain irradiation that the discursive nucleus of the subject traveled until it was clinically observed as a phenomenon.

In view of this, it is found in the considerations of Freud (1930), who to elucidate the quality of what acts the analyst's desire, the drug practice is accepted in what aims to protect against frustration with the real world. The efficacy of toxics lies in desensitizing the patient in the face of the misfortunes of neurotic life, so that the drug subverts the chemistry of the body and makes the subject enjoy even remaining immersed in the hostile world of castration. Thus, the psychoanalyst should pay attention to the latent symbolism in the efficacy of the drug, considering that in the struggle for happiness, intoxication produces immediate pleasure and a sense of independence from the external world, which is set to promote displeasure. 
In view of this, it is considered that the purpose of human life (FREUD, 1930) is precisely the search for happiness and the pursuit of pleasure. The subject intends the success of the libidinal economy and works for the avoidance of suffering aiming at full satisfaction. In this sense, the principle of pleasure dictates routes that aim at psychic homeostasis, even in its most exaggerated appearances such as intoxication. Thus, this phenomenon constitutes an attempt to neutralize the neurosis of the subject, who is in this world without being able to get rid of it.

Narcotics act alongside impulses that have not submitted to civilization and have taken forbidden objects to satisfy themselves. Considering this association, the analytical situation perceives a prohibition on the impulses that could be repressed and admits that this interdict is beyond the legal law, on a subjective and unconscious level. What is scanned is the Oedipal and particular history of each subject, in which they watch the symbolic interdiction and sometimes leads the subject to rebel against the castration of impulses. (FREUD, 1930).

It is agreed in this work that, as the main source of suffering for the subject, human relationships have repercussions on the way he deals with his impulses. Despite the fact that the neurotic chose to live through love (FREUD, 1927), the vicissitudes of human relations can lead the subject to object choices that dispense him with the danger of love. The predilection for the drug figures as one of these options. Thus, it takes care here of the toxicomaniac phenomenon as a subtype of a malaise that, despite commonly reaching the neurotic subjects, is subjected by each in its own way.

Having said that, psychoanalysis considers that the nominalist custom of observing drug-dealing practice in reality continues to be insufficient to account for the consequences of the real interdiction. It is in this sense that the analytical technique transposes its focus to a terrain that is not observable at first sight and does not guarantee advance appointments, as it is not concerned with establishing itself as an absolute knowledge. Thus, it is not objective with the present work, to draw a complete inventory of how psychoanalytic concepts offer solution to the toxicomaniac issue, but on the contrary, to rescue the central notion of subject of the unconscious (FREUD, 1900 ) and how the analyst summons him through the toxicomaniac phenomenon. 


\section{THE UNCONSCIOUS KNOWLEDGE OF THE SUBJECT}

To found the instrument with which the subject of this work is approached, "The Interpretation of Dreams" (FREUD, 1900, p. 406) brings notions that pinel's psychiatry was missing. Here, a third element is founded without which we do not propose to consider drug addiction. We then take the word in what it establishes in itself an unconscious language and itself. This element can be represented by acts of repetition with symbolic value of speech. In view of this, recidivism in drugs occurs by the belief of the subject in the reliability with which the object makes him revive a past satisfaction, and points to an unconscious language that underlies this satisfaction.

To challenge the pleasure in this repetition, the relationship with the object is considered as an irrevocable relationship of lack of object (LACAN, 1956). This relationship between patient and object is not direct, but transposed through a hole. Because of this, it cannot be taken as the center of the analytical situation, but it is used for the lack to be revealed to the subject.

Having said that, the analyst interposes his interpretations not at any point, but where the derivative of the lack signifier - the drug - simulates buffering the hole. Thus, one does not directly target intoxication, but the symbolic process that it covers up. The concept of castration (LACAN, 1956) is then approached as an unfolding of the insufficiency shown by the signifier of the Other in the constitution of the subject. Therefore, it is understood that the power of treatment is in opportunistic awareness that, if even the Other in relation to whom the patient submitted his self, led him to disenchantment, the substitute who tries to fulfill his function also did not succeed.

Thus, by taking the unconscious as a cause, the analyst leads the patient fixated on the drug to conclude that even the toxic ones when they make the body enjoy appearing to silence castration, are not able to annihilate the effects of it.

Moreover, despite considering the object relations as fundamentally perforated, without being able to focus on them, it is from the hole that structures the search in the relationship with the drug, that desire is found as a truth where the analyst effectively 
stands up. Moreover, it must be understood that first the desire affects the subject and the subject already affected by a cause, affects and chooses the object (LACAN, 1958). In this relationship, like the object, the desire itself also does not have a real representative, however, as it is located in the subject himself and not outside, he has chances of more authentic exits to account for castration. It is then based on the relationship of hiance with the drug object to the promotion of desire, without disregarding that even what is most authentic in the subject is not reached without hindrance.

Therefore, as Proposed by Lacan (1959), this study takes the fundamental fantasy of the subject as the faithful form of the object relationship. The value of this fantasy in the approach of the phenomenon discussed here is to demonstrate not only the neutered subject and the drug of which it uses as an object of obstruction, but above all the desire that moves its psychic apparatus. By being able to situate himself in his own fantasy through his desire, the subject can emerge as truth, rather than an echo of the desire of another someone who had once captivated him by language. Thus, the patient will recognize a desire outside of himself, and that his own does not admit object of satisfaction, thus entering another stage of its constitution as being: the drive maturation.

Moreover, intoxication as a flawed investment to name the situation of the subject in the symbolic world, opens space for the emergence of desire, before which this subject will again attempt an appointment that will also fail (QUINET, 2000). The analysis will provide the subject with the analytical discourse that deals with this unfeasibility. That is, the subversion of the true symptom is found in all cases, in the subject himself, as he maintains with the real of himself the opposition to what constituted him symbolically and imaginatively.

Having said that, the analyst recommends not eradicating the drug practice, so as to locate where the subject's satisfaction with the object first lodges. The choice of the drug seems to guarantee the patient to have found a way to enjoy that regardless of the one for whom one day came frustration - the Other. However, what Santiago (2001) proposes is that in the toxicomaniac act the subject does not seem to seek a substitute 
object for his relation to the Other. Thus, the author argues that the so-called 'drug addict' implies taking phallic jouissance as a solution in itself, when he shows that he has found a non-genital object that satisfies his search and disqualifies castration.

In summary, taking the subject's word by rail, it is discovered that the ruling principle of drug practice does not only show the maximization of pleasure and the removal of displeasure as a practical goal closed in itself. There is in the meantime the drive dynamics with the object, a jouissance that is justified in the history - and only there of the subject. Therefore, [...]the "subject as he speaks can find entirely his answer, his return, his secret, his mystery, in the constructed symbol". (LACAN, 1954, p. 252).

\section{THE ANALYST'S WISH}

Here is the last operator of the analysis that we will deal with: the analyst's desire. After the research has indicated how primordial it is to focus on the unconscious knowledge of the subject and his desire for the same quality, it will show the peculiarities and implications of this other desire. In this sense, despite the analyst's desire to present himself throughout the analysis, it is considered that it is after opportunistizing the appearance of unconscious knowledge that he opens the way for the subject to throw himself at another stage. Thus, after the patient has taken the treatment for what directs his satisfaction in the drug to his pulsation, the analyst with his attentive desire (LACAN, 1960), also provokes the recognition by the subject about the characteristics of his own desire.

Having said that, after the moment when the analyser succeeded in sustaining the analytical dialogue and the impossibility of naming his desiring condition, he will be led to perceive this desire as what is bound by the law, as the desire of the Other. The analyst's desire works to propel the subject to the transgression of the law of the Other in what does not mean non-compliance with the constitutional law of society. In fact, it promotes in analysis, the de-subjection to a symbolic statute that ended up deregulating the authentic functioning of this subject. Thus, when faced with the true causes of drug practice, the patient is faced with the inconsistency of the Law's Other 
(QUINET, 2000), however, it is not left to luck, since the analyst's desire begins to occupy the place of helplessness, but without the Other, without the Law.

Thus, even if this desire takes the place of inconsistency, he himself keeps a riddle (QUINET, 2000). If the subject seeks what the analyst thinks about his drug addiction or what his knowledge proposes for this phenomenon, he/she will find no judgment, making it impossible to interpret this desire. This is because the analysis operates so that each one judges for himself, only making the character of these choices evident so that the subject does not decide on his own ignorance. Thus, it is the knowledge of the subject that founds the analyst's desire, and not the other way around, as classical psychiatry suggests.

Moreover, the analytical technique does not even aim to "treat drug addiction", as the analyst's desire is elsewhere, other than that of healing, release, purge or help to others. It is opposed, for example, to the moral treatment proposed by Pinel to account for reorienting the misguided to reason (BERCHERIE, 1989). While psychiatry has been instrumentalized in the repressive institutions and the idea that the patient's mind was affected by their perceptions, the analyst also considers the environment and the psychic reality of the subject, but bets on a space of speech and the (re)symbolic constitution of the unconscious.

Finally, the analyst's desire admits the subject's unconscious desire, but differs from it in that it does not respond to any demand, and offers room for the subject's desire also not to prime by answering. The analyst's desire does not speak of a personal desire to know, but is the place of a know-the-less (LACAN, 1969), a position that exists solely for the cause. Thus, this desire tells of the supreme goal of enabling the existence of being, separating it from the unconscious bonds contracted by symbolic inheritance.

\section{CONCLUSIONS}

This work has undertaken a considerable theoretical investigation that concludes, however, in a concise idea: that the phenomenon holds a history and this is the personal history of the subject who drugs himself. Thus, the analyst's desire is an 
engine, not of cure, but of questioning about a repetition with precedents in the repeater itself. It is as in all experience of analysis, a clinic of discovery, but not of knowing a priori or desire to heal, in which the patient builds his own paths (LACAN, 1960) for the outcome of repetition. In view of this, the relevance of this work is extracted in what it reiterates a technique that values the autonomy of the subject in drug practice.

The research leads us to induce that, like any of the patients, what seeks the subject who drugs himself is happiness. Taking this into account, what the analytical situation questions is "Crossed by what parameters does the subject search? What does he know about the nature of this desired happiness, why do he do what he does to achieve it?"

Thus, we take the relevance of the toxicomaniac phenomenon in which its study contributes socially and to the clinic one by one, without giving itself to generalizations, even in the face of the recurrence of the phenomenon. The analyst's desire works in order to shed light on an unconscious and particular knowledge. In this sense, to the extent that the self is an instance of ignorance in the subject because it is referring to the Other, a more intimate sphere is aimed at reaching its truth. For this, the following path is taken: speech as access to the unconscious truth of the subject in the face of intoxication. Thus, it is admitted not to know a priori about what the subject's speech is about (LACAN, 1956), but it is taken as a route for access to beyond the toxicomaniac phenomenon.

\section{REFERENCES}

BERCHERIE, Paul. Os fundamentos da clínica: história e estrutura do saber psiquiátrico. Rio de Janeiro: Jorge Zahar, 1989.

FREUD, Sigmund. A interpretação dos sonhos, parte I. Edição Standard Brasileira das Obras Completas de Sigmund Freud, vol. IV. Rio de Janeiro: Imago,1996. A interpretação dos sonhos, parte II. Edição Standard Brasileira das Obras Completas de Sigmund Freud, vol. V. Rio de Janeiro: Imago,1996. 
. O Mal Estar na Civilização. Edição Standard Brasileira das

Obras Completas de Sigmund Freud, vol. XXI. 2. ed. Rio de Janeiro: Imago, 1988.

LACAN, Jacques. O seminário, livro 1: os escritos técnicos de Freud. 2. ed. Rio de Janeiro: Jorge Zahar, 2009.

. O seminário, livro 2: o eu na teoria de Freud e na técnica da psicanálise. 2. ed. Rio de Janeiro: Jorge Zahar, 2010.

. O seminário, livro 4: a relação de objeto. Rio de Janeiro: Jorge Zahar, 1995.

. O seminário, livro 6: o desejo e sua interpretação. 1. ed. Rio de Janeiro: Jorge Zahar, 2016.

. O seminário, livro 7: a ética da psicanálise. Rio de Janeiro: Jorge

Zahar, 2008.

O seminário, livro 11: os quatro conceitos fundamentais da psicanálise. 2. ed. Rio de Janeiro: Jorge Zahar, 2008.

O seminário, livro 17: o avesso da psicanálise. Rio de Janeiro: Jorge Zahar, 1992.

QUINET, Antonio. A descoberta do inconsciente: do desejo ao sintoma. 7. ed. Rio de Janeiro: Jorge Zahar, 2018.

SANTIAGO, Jésus. A droga do toxicômano: uma parceria cínica na era da ciência.

2. ed. Belo Horizonte: Relicário Edições, 2017.

Sent: March, 2020.

Approved: April, 2020. 